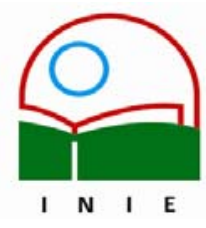

Universidad de Costa Rica

Facultad de Educación

Instituto de Investigación en Educación

ACTUALIDADES INVESTIGATIVAS EN EDUCACION

\title{
GROUPING TECHNIQUES IN AN EFL CLASSROOM
}

\section{Marlene Ramírez Salas ${ }^{1}$}

\begin{abstract}
This article focuses on the need for English language teachers to use group work as a means to foster communication among students. The writer presents a definition of group work, its advantages and disadvantages, some activities for using group work and some grouping techniques created or adapted by the writer to illustrate the topic.
\end{abstract}

Key words: DEFINITION OF GROUP WORK ADVANTAGES AND DISADVANTAGES OF GROUP WORK ACTIVITIES/ PLANNING/ TECHNIQUES/

Resumen: Este artículo manifiesta la importancia del trabajo grupal en el aula, para motivar la comunicación entre los estudiantes. Asimismo, presenta la definición de trabajo en grupo, sus ventajas, desventajas y algunas actividades y técnicas para formar grupos.

Palabras clave: DEFINICION DE TRABAJO EN GRUPO/ VENTAJAS Y DESVENTAJAS DEL TRABAJO EN GRUPO/ ACTIVIDADES/ PLANEAMIENTO/TECNICAS/

For many years English teachers have been using a variety of techniques to encourage interaction and participation among learners. One of the most common activities that teachers do is groupings as Kramsch (1992) says

speaking a language means more than referring to the world, it also means relating to one's interlocutor. It is through the interaction with this social group that the language is used and learned, and the group is given a social identity and a social reality (p.17).

No one can deny that learners like to work in groups, and if they do a good job, the benefits are many. However, due to the overuse of groupings, EFL teachers sometimes lose track of what working in groups really means. This article intends to provide a general overview of group work, advantages and disadvantages of group work, some group activities, the process to have successful group work, and finally, some creative ideas for groupings.

\footnotetext{
${ }^{1}$ Master en la Enseñanza del Inglés como Lengua Extranjera de Southern Illinois University. Bachiller en Inglés de la Universidad de Costa Rica. Labora para la Universidad de Costa Rica desde 1993 en la Escuela de Lenguas Modernas impartiendo cursos a nivel de Bachillerato, Licenciatura y Maestría.

Correo electrónico: marami@racsa.co.cr
}

Artículo recibido: 30 de noviembre, 2004 Aprobado: 28 de marzo, 2005 


\section{Definition of group work}

It is important to start by defining what group work is. According to Brown, (2001)

it [ group work] is a generic term covering a multiplicity of techniques in which two or more students are assigned a task that involves collaboration and self initiated language. It implies small group work, that is, students in groups of perhaps six or fewer (p.177).

Three important aspects should be highlighted in this definition. The first one is collaboration, in other words, cooperation. Students have to work together for the completion of the task. All the members of the group are like the pieces of a machine, if one does not work well, a malfunction may occur. Obviously, for lazy or irresponsible students, this is not a problem because the other members will take over and will make the machine work somehow. But real cooperation in group work occurs when everyone is aware of his/her responsibility and role and commits himself/herself to accomplish it in the best way possible. Kagan (1994) affirms

that division of labor is often established by assigning task roles (Student One is to research the historical character's early life; Student Two, his inventions,; Student Three, his married family life; Student Four, his major inventions) or maintenance roles (Student One, you are the Materials Monitor; Student Two, you are the Quiet Captain; Student Three, you are the Task Master; Student Four, you are the Recorder) (p. 10).

Of course, all the members work together, discuss, come out with new ideas, change certain things, but if one does not comply with his/her role, the work is paralyzed. Also, roles are changed within the group every time a new task is assigned; in this way, everybody will have a different responsibility each time a new group work is assigned. This is what Kagan (1994) calls interdependency: "the success of every team member depends on the success of each member (if one fails, all do), then a very strong form of positive interdependence is created and team members are very motivated to make sure each student does well' (p. 7). At first, roles can be assigned by the teacher, but later on, as students get better trained on successful group work, they can be responsible for assigning roles themselves.

The second and third aspects in Brown's definition are very related. Self initiated language refers to students using what they know and have learned in class to communicate with others in the classroom. In order to do this, the groups have to be small, as Brown previously suggests six students or fewer. In very big groups, shy or passive students tend to fall in silence and let the most talkative ones do the talking. Nunan (1999) also points out that 
one of the classroom variables that has had a marked effect on student participation in oral activities has been group size. Students who remain silent in groups of ten or more will contribute actively to discussions when the size of the group is reduced to five or three. (p. 157).

\section{Advantages of group work}

Once group work has been defined, it is important to analyze why EFL teachers use group work. I personally consider that group work is not just a time-filler, or a thoughtless activity that teachers sometimes use for checking pending papers or extra assignments. Group work should not be used as class time for teachers to read, to rest, to prepare other classes, or just to imitate other teachers that are using group work without really understanding what that is and entails. The real purpose of working in groups in an EFL class goes beyond the actual command: "Get in a group, please, and answer the following questions," which, in most of the cases, turns out to be individual work.

Brown (2001) and Harmer (2003) pinpoint the following principles in which group work is grounded:

- Students' processing language moves from units and pieces to more complex sentence structures faster and spontaneously. "Overanalyzing language, thinking much about its forms, and consciously lingering on rules of language all tend to impede this graduation to automaticity" (Brown, 2001, p.56). The key element here is fluency over accuracy

- Group work gives students more chance to interact and use the target language more freely. Instead of just having a few seconds to talk in teacher-fronted classes, students can participate longer in a small group and feel more confident to give their opinions and even make mistakes when just three or four classmates are looking at them. Brown (2001) states that "small groups provide opportunities for student initiation, for face-to-face give and take, for practice [ sic ] negotiation of meaning, and for extended conversational exchanges, and for students adoption of roles that would otherwise be impossible" (p.178).

- Language learning is much more meaningful. Instead of memorizing and/or drilling, students use language to talk about something that is appealing, contextualized and relevant to them. "Meaningful learning will lead toward better long-term retention than rote learning" (Brown, 2001, p.57). 
- Group work creates a positive atmosphere in the sense that some students will not feel vulnerable to public display that may cause rejection or criticism. It is totally true that shy or low risk-taker students feel much more confident working in small groups than in teacher-fronted classes. It is difficult to hide in small groups.

- Learner's responsibility and autonomy are encouraged through group work. "The small group becomes a community of learners cooperating with each other in pursuit of common goals" (Brown, 2001, p. 178). Students are not constantly relying on the teacher to complete their tasks. They learn that they can complete an activity successfully with the help of other classmates or by themselves.

- Group work supports and reinforces the application of the multiple intelligences theory in which learners make use of their individual abilities to accomplish a task. In this way, learners can participate by doing what they like or are very good at, for example, drawing, writing, reporting, among others.

- By using group work the teacher has the opportunity to teach turn-taking mechanisms. As Kramsch (1992) suggests

teaching students how to take turns, as easy as this might seem, requires teaching a number of skills that are not automatically transferred from the mother tongue such as to tolerate silences, to direct gaze to addressees, to make use of floor-taking gambits, and to take longer turns (p. 22).

\section{Disadvantages of group work}

As everything in teaching, group work has also disadvantages that are important to explore. The first drawback relates to noise. Obviously, students speak all at once trying to accomplish their task, and this causes noise that may bother other colleagues. But as Doff (1991) states "the noise created by group work is usually "good" noise since students are using English and are engaged in a learning task" (p. 141). What a teacher can do to solve the "noise problem" is to make students aware that they do not need to shout to be heard and this will help to keep noise a at moderate level.

Another negative aspect of group work is the fact that some teachers may lose control of the class or have difficulties controlling the class, especially what concerns to discipline. However, even if students are working in small groups and are in charge of the completion of a task, the teacher is still the director and manager of the class and needs to make students aware of this. Doff (1991) highlights that in order "to stop activities getting out of control, it is important to give clear instructions, to give clear defined tasks and to set up a routine so that 
the students exactly know how and what to do" (p. 142). If a teacher circulates around the class to clarify doubts and to monitor what students are doing, there is no reason for losing control of the class.

The use of native language and lack of correction of mistakes represent another dislikable feature of group work. This is true even in teacher-fronted classes. Students make use of any opportunity to switch to their native language. To avoid this, Brown (2001) suggests "to encourage students to practice using the target language in face-to-face contexts and to make them aware of the importance of some real uses for English in their own lives" (p.180). When working in groups, students are surely going to make mistakes. But as Brown points out (2001) "errors are a necessary manifestation of interlanguage development, and we do well not to become obsessed with their constant correction. Wellmanaged group work can encourage spontaneous peer feedback on errors within the small group itself' (p. 181). We, teachers, are facilitators and guides, not police officers to stand behind our students' backs in order to correct everything they say or do. Nowadays, language teaching is heading towards autonomous learning not towards dependent learning.

\section{Group work activities}

Penny Ur in her book Discussions that Work presents a very good list of group activities that language teachers can incorporate in their classes. In this section the reader will find a list taken from Ur with some other activities practiced by myself. The list includes activities like:

DISCUSSIONS

DEBATES

PROBLEM-SOLVING SITUATIONS

SIMULATIONS / ROLE PLAYS

NEWS FORECAST

CREATION OF A STORY, FASHION SHOW, TALK SHOW

DRAMATIZATION

CREATION OF A SURVEY OR INTERVIEW

INFORMATION GAP ACTIVITIES / JIGSAWS

BOARD GAMES AND CONCENTRATION GAMES

WRITING A CLASSIFIED AD, AN OBITUARY, A LETTER TO THE EDITOR PROJECTS (COLLAGES, ADVERTISEMENTS, FUND RAISING CAMPAINGS TO 


\section{HELP THE ENVIRONMENT OR A COMMUNITY, PLANNING A TRIP OR PARTY) \\ DETECTING DIFFERENCES FROM PICTURES}

PICTURE / SENTENCE SEQUENCE

$(U r, 1990)$

Obviously, the selection of these activities will highly depend on the topic being studied, the level of the students, the dynamic of the group and the class time. It is also important to remember that choosing one of the activities above entails a great deal of work for the teacher since s/he needs to find an appealing content, to make a good connection between the content of the activity and the topic of the unit, to write clear instructions, to think about useful expressions for students to carry out the task, and finally, to define the roles of each team member, making sure students have equal responsibilities. All these steps will be clearly developed in the following section.

\section{Planning group work}

In order to get successful group work in foreign language classes, Brown (2001) suggests a series of steps in which the teacher should always

1. INTRODUCE THE TECHNIQUE: Students need a clear explanation of the activity they will carry out. Learners must know the topic, the number of members they will work with, the time allotted to make the activity, what their responsibilities are, the points they will obtain once the activity is finished, among others.

2. MODEL THE TECHNIQUE: Once students have an idea of what they are supposed to do, the teacher should model or exemplify what students will do, if possible. Tasks like debates, discussions, or problem-solving situations cannot be modeled entirely, but at least it is the instructor's responsibility to make the main characteristics clear to students.

3. GIVE EXPLICIT INSTRUCTIONS: Restating what Doff mentions before, instructions must be crystal-clear. They should be short, precise, and with simple words. If an instruction contains several steps, the teacher should highlight those steps by using roman numerals, letters, or numbers bold-faced and with a readable font size. In this way, students will notice the different parts of the activity, and the way they should complete it. 
4. GIVE USEFUL EXPRESSIONS (GAMBITS): One of the most important aspects a teacher should take into account when preparing an activity for group work is to think about all possible expressions students will need to carry out the activity. These expressions or gambits will force students to use English and to avoid the use of the mother tongue.

Some of these gambits are:

It's your turn.

Go back to start.

Draw a line from to

Switch the pictures.

Give the scissors.

Change the card.
Toss / pass the dice.

Let's glue this piece here.

Why don't we ?

Don't cheat.

Throw the dice again.

This is wrong, Let's start again!

These gambits must be explained and practiced before the activity starts. They should also be written down in a place where students can easily see them.

5. DIVIDE THE CLASS INTO GROUPS: It is a good idea to use a variety of grouping techniques to make students work with different people every time a new activity is assigned. Some ideas of grouping techniques will be presented at the end of this article.

6. ASSIGN ROLES: Even though students know their own abilities very well and can assign themselves their own roles, it would be a good idea if the teacher can say what every member of the group is responsible for. In this way lazy or irresponsible students would be forced to work hard and to participate as much as the other team members.

7. CHECK FOR CLARIFICATION: It is very important to verify if students have understood what they have to do. One way of doing this is by asking learners to explain the instructions back.

8. SET THE TASK IN MOTION: Once steps 1 to 7 have been completed, the teacher asks students to start the activity.

9. MONITOR THE TASK: The teacher should constantly walk around the room to monitor what students are doing. Students usually like to ask questions, clarify doubts, or even make the teacher another member of the group for a few minutes. During this step, the teacher can write down certain mistakes in grammar, pronunciation or vocabulary to give feedback at the 
end of the activity. Also, depending on the activity, this would be a nice moment to grade the students unnoticeably.

10. SET A TIME FOR DEBRIEFING AND FEEDBACK: This last step is fundamental to make an activity valuable. Students need to present and to share what they did. Sometimes, because of lack of time, teachers do not go through this step, but students do need to be rewarded and praised for what they did. They also need feedback to correct or reinforce certain weak areas. By doing general comments in relation to content, language use and discipline, learners will clearly see the main purpose of the activity.

\section{Grouping techniques}

Throughout years of teaching experience, I have noticed that language teachers make use of just a few ways of grouping students. One of the most common techniques is by giving numbers to students and then grouping them according to their numbers. Another one, which I consider the easiest one, is by asking students to get in trios or fours. I do not particularly see anything wrong with this; however, students love to group with their soul mates, and many times this turns out to be very disturbing and annoying.

In order to introduce a little bit of variety in the classroom and to group students at random, I suggest some techniques that I have created myself. I have also tried them out and have had very positive results in my English courses. These techniques are:

1. Using birth dates or zodiac signs. Ask students to stand up and ask their classmates when they were born or what their zodiac sign is. Ask students to group according to the month in which they were born or their zodiac sign. If there are many students grouped with the same birth month or zodiac sign, split them in two groups to have a manageable group size. It is important to notice that in this process of making students group, they are actually using the language and practicing important questions that sometimes are hard for them because of the grammatical structure.

2. Postcards / pictures /drawings. Take a postcard, picture or drawing and cut it in pieces with different shapes as to form a puzzle. The number of pieces will depend on the number of members wanted in the group. Also, the quantity of postcards, pictures or drawings will depend on the number of groups to be formed. Ask students to take one piece of the puzzle, 
to stand up and to look for the rest of the pieces to form the puzzle back together. Once the students have put all the pieces together, they will form a group.

3. Pictures / drawings. If cutting and forming puzzles is too troublesome, just look for pictures or drawings that belong to the same category. For example, try to find pictures of birds, cats, butterflies, bears, cars, volcanoes, rivers, trees, etc. Ask students to take one picture and group with the other two or three that have the same picture category. A variation of this activity can be done with chocolates or candies in which students have to group according to the kind of chocolate or candy they have. Although this activity may sound childish, grownups and adults love it, and they indeed have fun looking for their partners.

4. Words closely related in meaning (synonyms / antonyms). Look for words that have been previously explained and studied in class and use them as a grouping technique. Synonyms or antonyms can either be used. Give each student a piece of paper with the word written down and ask him/her to stand up and look for two or three synonyms or antonyms of the word he/she has. Once the student has found his two or three partners, they sit down and start working on the assigned task. This grouping technique will look like this:
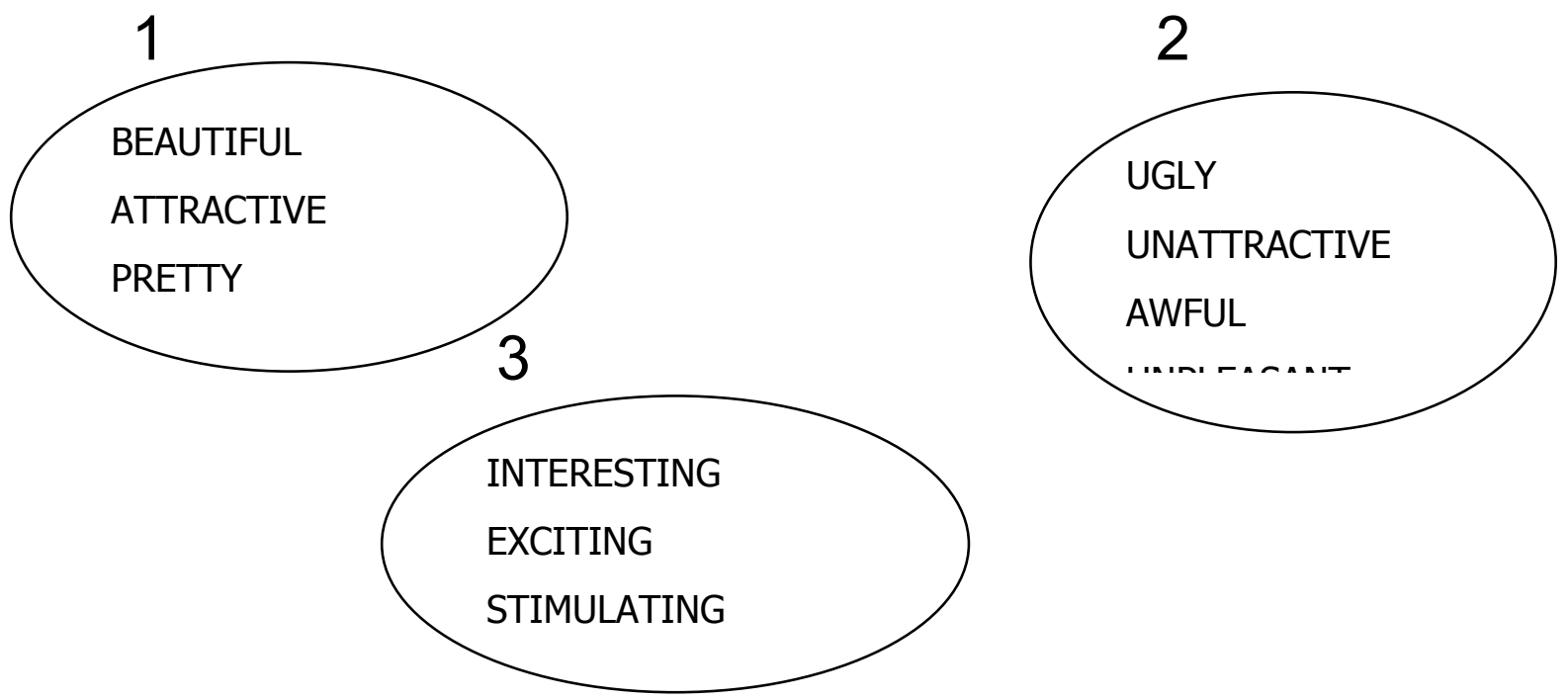

5. Pronunciation. This technique not only helps to form groups, but also helps students to review pronunciation in a fun way. Choose sounds that have been practiced in class, give one word with that particular sound bold-faced and underlined to each student. Students 
have to look for two or three partners with a word containing the same sound. The activity looks like follows:
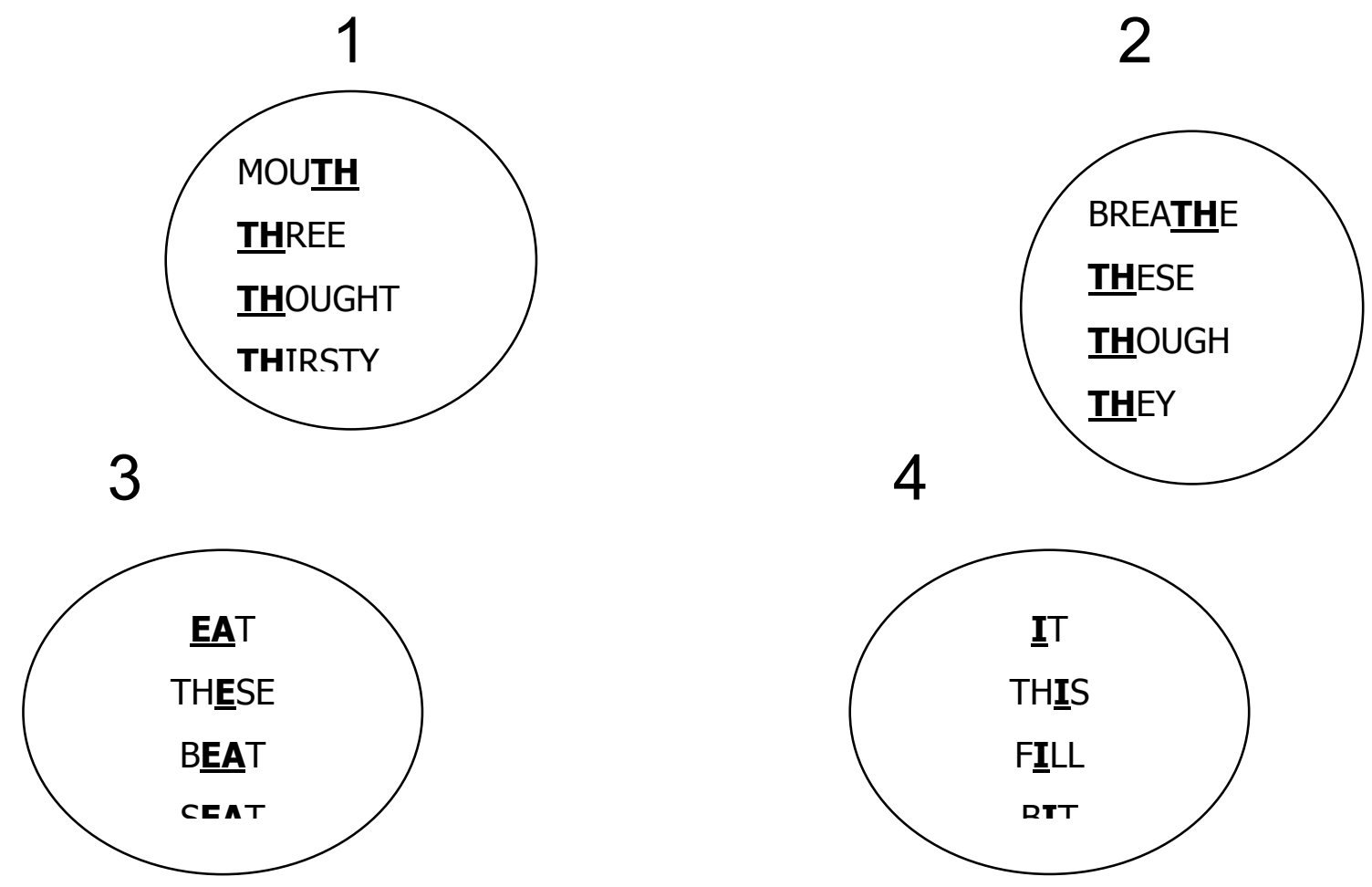

6. Proverbs or idiomatic expressions. Choose proverbs, sayings or idiomatic expressions that have been studied in class and divide them in two, three or four parts. Again, the number of parts will correspond to the size of the group. Give each student a piece of paper with one part of the proverb and ask him/her to look for the rest to complete the proverb. This is a nice way of reviewing proverbs and vocabulary that students sometimes forget and of helping them internalize linguistic aspects of a foreign language. This activity will look like this:

1.
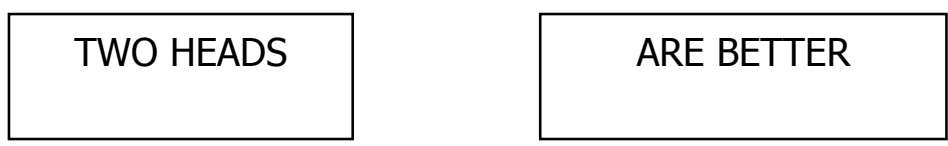

THAN ONE

2.

\begin{tabular}{|c|c|c|c|}
\hline $\begin{array}{c}\text { IN THE } \\
\text { HAND }\end{array}$ & IS WORTH & $\begin{array}{c}\text { TWO IN THE } \\
\text { BUSH }\end{array}$ \\
\hline
\end{tabular}


3.

THE GRASS IS

\section{ALWAYS GREENER}

ON THE OTHER SIDE
OF THE FENCE

7. Definitions. For this activity words with three or more definitions should be used. The main idea here is to review vocabulary that has been studied in class and that has more than one connotation or meaning. One student will have the main word and will have to look for the other three or four words that have the other meanings. The technique is like this:

1.

PARTY

A SOCIAL MEETING

\section{A POLITICAL GROUP}

2.

SHOT

A BULLET FIRED
FROM A GUN

A GUESS, TRY
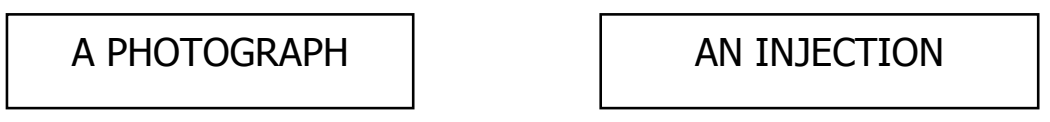
A DRINK OF LIQUOR

8. Topics. Group students according to the different topics studied in class, especially if you have covered more than four topics in a course, or if you know that students have covered those topics in previous courses. Topics like food, music, movies, cities /countries are very easy to use. For example, if food is chosen, think about different categories (the number of categories corresponds to the number of groups) within this topic like grains, drinks, vegetable, fruits and fast food. Think about products related to those categories and 
write them on small pieces of paper. Distribute those pieces and ask students to group themselves according to the category they have. The activity will look like this
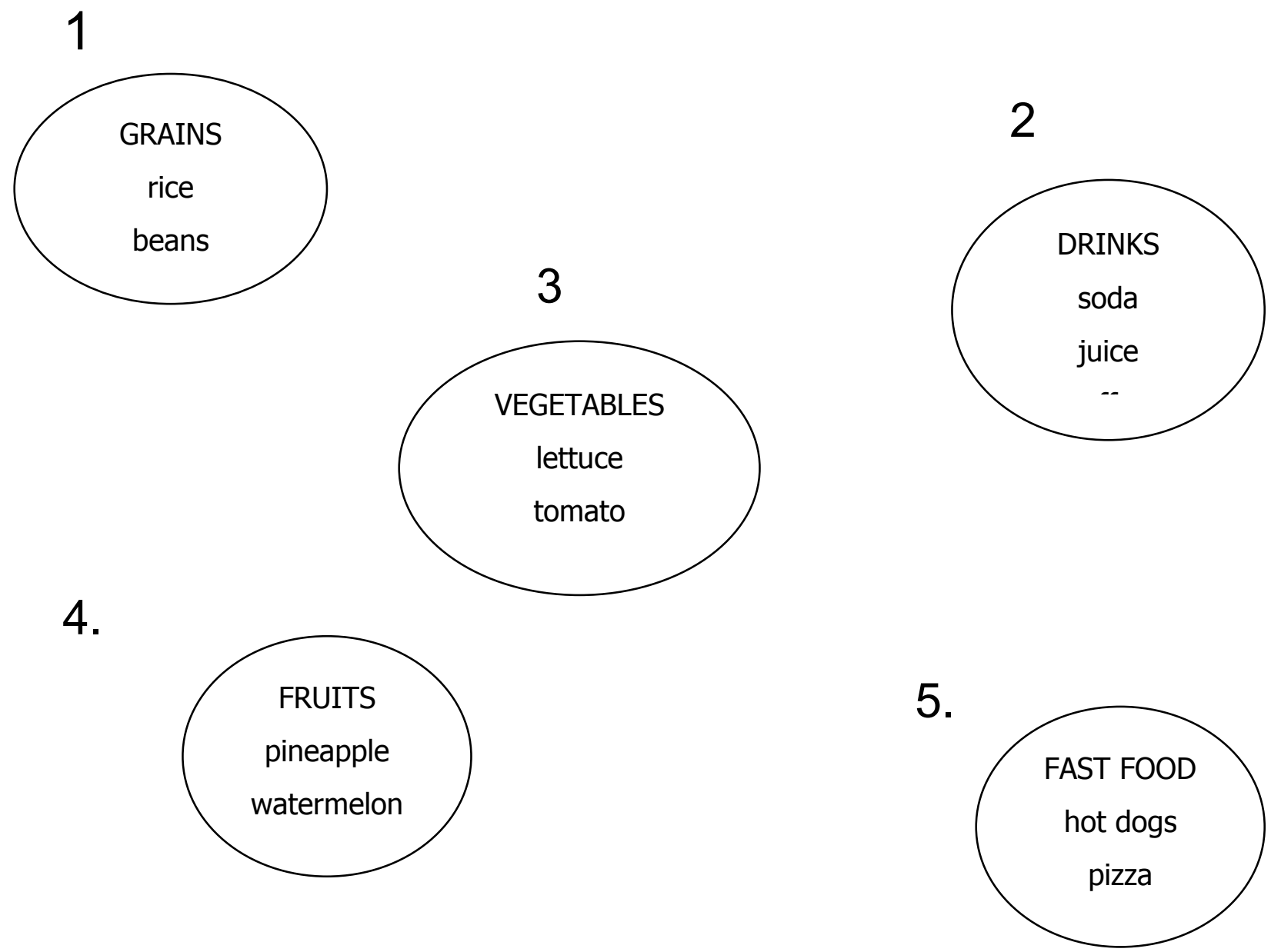

9. Subtopics or subtitles. Longer readings can also help to form groups and to avoid having troublemakers sitting together in the same group. It is a good idea to choose readings that preferably contain subtitles or subtopics. Just prepare small slips of paper with the subtopics or subtitles of the reading. If you want groups of four, you will write one subtopic on four slips of paper and students with that subtopic will have to sit and work together. Once groups are formed, students will have to answer some questions about the subtopic used to group them together, to explain the main ideas of that subtopic, and to prepare a short presentation about that subtopic to the rest of the class. In this way, all groups will be presenting something different and they will have to pay attention to their classmates to make sense of the complete reading. By doing this activity, the teacher will change the dynamics of the class by allowing students to present the reading, instead of having a teacher-fronted discussion, and will give all students the opportunity to say something about the reading. 
One important aspect that teachers have to remember when putting these ideas into practice is that everything teachers use as grouping techniques has to be previously studied and explained during class time. It would be a total failure if teachers use words, concepts, or expressions to group students if they do not know what they mean. The main idea of these grouping techniques is not just grouping students, but reviewing language aspects creatively.

\section{Conclusion}

One of the main aspects that human beings have to learn to deal with as they grow up and participate in society is to work in groups. As language teachers, we cannot leave this aspect aside; on the contrary, we have to incorporate it in our classes and teach students to get the best out of it. Despite the great intentions of teachers to make students talk and participate more in foreign language classes, they sometimes fall short of their goal because of time constraints and fall into the routine of teacher-fronted classes. As Kramsch (1992) states "traditional forms of classroom interaction need to be reassessed in the light of the new language to help learners move from institutional productivity to productive conviviality" (p.28). Group work helps students and teachers to bridge the gap between input and output. In other words, students show what they have learned by playing and using language with their peers. They also have the chance to have a small piece of reality in their classes by negotiating, turn-taking, suggesting, and getting to a final result. This is what human beings do every day, so why don't we bring that into our languages classes too? 


\section{References}

Brown, D. (2001). Teaching by Principles: an interactive approach to language pedagogy. New York: Addison Wesley Longman, Inc.

Doff, A. (1991). Teach English: a training course for teachers. New York: Cambridge University Press.

Harmer, J. (2003). The Practice of English Language Teaching. Oxford: Longman

Kagan, S. (1994). Cooperative Learning. U.S: Resources for Teachers, Inc.

Kramsch, C. (1992). Interactive discourse in small and large groups. In W. Rivers (Ed.), Interactive Language Teaching. New York: Cambridge University Press. 17-30

Nunan, D. (1999). Second language teaching and learning. Boston: Newbury House

Ur, P. (1990). Discussions that work: task-centered fluency practice. New York: Cambridge University Press. 